\title{
Enzymatic-Organo-Catalyzed Oxidative Rearrangement of Tertiary Allylic Alcohols: Synthetic Applications and Integration into a Cascade Process
}

\author{
Elisabetta Brenna, ${ }^{\mathrm{a}, \mathrm{b}}$ Michele Crotti, ${ }^{\mathrm{a}}$ Matteo De Pieri, ${ }^{\mathrm{a}}$ Francesco G. Gatti, ,a,b Gabriele \\ Manenti, ${ }^{a}$ and Daniela Monti ${ }^{\mathrm{c}}$ \\ a Dipartimento CMIC “G. Natta”, Politecnico di Milano, Via Mancinelli, 20134, Milan, Italy \\ Fax: (+39)-23993080; phone: (+39)-23993072; e-mail: Francesco.gatti@polimi.it \\ b The Protein Factory, Politecnico di Milano Università degli Studi dell'Insubria, Via Mancinelli 7, 20131 Milano, IT \\ c Istituto di Chimica del Riconoscimento Molecolare C.N.R. Via Mario Bianco, 9, 20131, Milano, IT
}

\section{Received: ((will be filled in by the editorial staff))}

Supporting information for this article is available on the WWW under http://dx.doi.org/10.1002/adsc.201\#\#\#\#\#\#

\begin{abstract}
A chemo-enzymatic catalytic system, comprised of Bobbitt's salt and laccase from Trametes versicolor, allowed the [1,3]-oxidative rearrangement of endocyclic allylic tertiary alcohols into the corresponding enones under $\mathrm{O}_{2}$ atmosphere in aqueous media. The yields were in most cases quantitative, especially for the cyclopent-2-en-1-ol or the cyclohex-2-en-1-ol substrates without EWGs on the side chain. Transpositions of tertiary alcohols bearing EWGs or macrocyclic alkenols were instead carried out in acetonitrile by using an immobilized laccase preparation. DehydroJasmone $^{\circledR}$, dehydro-Hedione ${ }^{\circledR}$, dehydro-Muscone and other fragrance precursors were directly prepared with this procedure, while a synthetic route was developed to easily transform a cyclopentenone derivative into transMagnolione $^{\circledR}$ and dehydro-Magnolione ${ }^{\circledR}$.
\end{abstract}

The rearrangement of exocyclic allylic alcohols was tested as well, and a dynamic kinetic resolution was observed: $\alpha, \beta-$ unsaturated ketones with $(E)$-configuration and a high de were synthesized. Finally, the $\mathrm{TEMPO}^{+} \mathrm{BF}_{4}^{-} /$laccase catalysed oxidative rearrangement was combined with the ene-reductase/alcohol dehydrogenase cascade process in a one-pot three-step synthesis of cis or trans diastereoisomer of 3-methylcyclohexan-1-ol with a high optical purity.

Keywords: Oxidation; Biocatalysis; Dynamic Resolution; Laccases; Ene reductases; Birch reduction; Wacker Oxidation; Fragrances.

\section{Introduction}

The [1,3]-oxidative rearrangement or transposition of tertiary allylic alcohols is a key transformation of organic chemistry (Figure 1a), ${ }^{1}$ especially for the synthesis of $\beta$ substituted or $\alpha, \beta$ disubstituted cyclic enones, which are wide spread structural moieties in the field of fragrances chemistry, ${ }^{2}$ either as keyintermediates or final products (Figure 1b).

The reaction is typically carried out in presence of a large excess of Chromium(III) based reagents such as pyridinium chloro chromate (PCC), Collins, Jones and many others. Although these oxidants are operationally simple and usually very efficient, their use on a large scale is impractical, since the wastes produced are notoriously very toxic and harmful. In this regard a significant improvement was achieved with the appearance of organic based oxidants, among which 2-iodoxybenzoic acid ${ }^{3}$ (IBX), 2,2,6,6tetramethylpiperidine-1-oxyl ${ }^{4}$ (TEMPO) and its oxoammonium fluoroborate salt ${ }^{5}\left(\mathrm{TEMPO}^{+} \mathrm{BF}_{4}^{-}\right.$, also a)

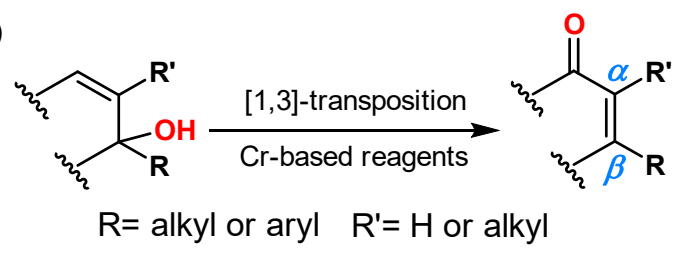

b)

dehydro Jasmone ${ }^{\circledR}$ dehydro Magnolione ${ }^{\circledR}$ dehydro Hedione ${ }^{\circledR}$<smiles>CC=CC1=C(CC(=O)OC)CCC1=O</smiles>

Figure 1. Oxidative [1,3]-rearrangement of tertiary allylic alcohols to give tri- or tetrasubstituted enones; b) Selected examples of cyclic enones based fragrances. 


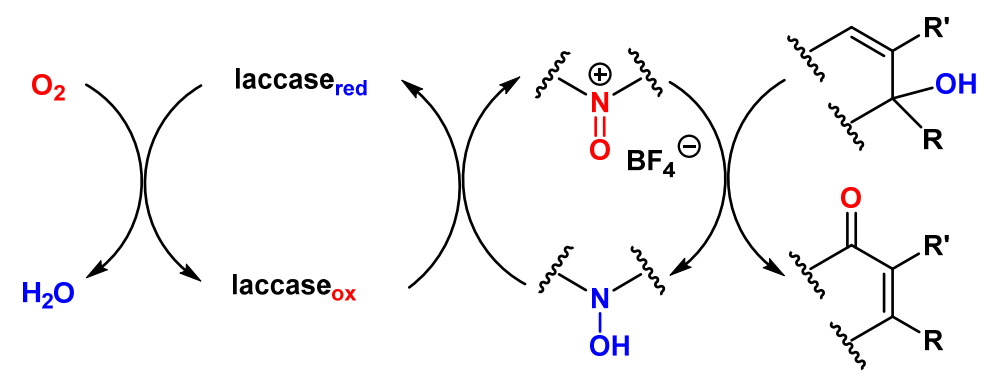

Figure 2. Proposed catalytic cycle in the oxoammonium/laccase mediated oxidative [1,3]-rearrangement of tertiary allylic alcohols to give tri- or tetrasubstituted enones.

known as Bobbitt's salt) are undoubtedly the most important. Considering the lack of a catalytic procedure ${ }^{3,5,6}$ in water, we feel that by combining the high efficiency of these oxidants with the typical advantages of the biotransformations might be an eyecatching goal.

In this regard, the TEMPO/laccase catalytic system ${ }^{7}$ has been one of the first examples of chemo-enzymatic procedures applied to the oxidation of several classes of organic compounds such as benzyl alcohols ${ }^{8}$ and diols. ${ }^{9}$ In addition, this catalytic system has been proficiently integrated with other biotransformations either in sequential multi-step ${ }^{10}$ or cascade processes. ${ }^{11}$

Laccases are metallo-proteins belonging to the family of oxidase enzymes, catalyse the reduction of $\mathrm{O}_{2}$ into $\mathrm{H}_{2} \mathrm{O}$ at the expense of sacrificial substrates, typically phenol derivatives, but also TEMPO is a substrate well accepted by laccases. ${ }^{7 \mathrm{t}, 12}$

Thus, keeping this in mind, we devised a new laccase-organo-catalytic system, consisting of an oxoammonium salt and Trametes versicolor laccase, using $\mathrm{O}_{2}$ as co-oxidant for the oxidative rearrangement of tertiary allylic alcohols (Figure 2).

\section{Results and Discussion}

First, we studied the oxidative rearrangement of 1methylcyclohex-2-en-1-ol, i.e. 1a, which was chosen as model compound for the optimization of reaction

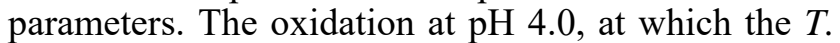
versicolor laccase exhibits its highest activity, ${ }^{12}$ under $\mathrm{O}_{2}$ atmosphere and in presence of a substoichiometric amount of TEMPO ${ }^{+} \mathrm{BF}_{4}^{-}(20 \%$ in mmol eq.) gave, after 24 hours, a mixture of enone $\mathbf{1 b}$, secondary allylic alcohol 1c and starting material in the ratio of 37:38:25 (conversions by GC-MS), respectively (Table 1).

At this $\mathrm{pH}, \mathbf{1 a}$ partially isomerizes to the more thermodynamically stable alcohol 1c (disubstituted alkene vs. trisubstituted alkene), reaching the equilibrium after 3 hours (1a/1c, 4:6 by ${ }^{1} \mathrm{H}-\mathrm{NMR}$, for the kinetic measurement see SI). Since, even after prolonged reaction times, just a small amount of secondary allylic alcohol 1c was oxidised into enone 1b $\approx 3 \%$, by GC-MS) we increased the $\mathrm{pH}$ with the scope of slowing down the detrimental acid catalysed 1,3 -allylic isomerizing side-reaction. ${ }^{13}$ Table 1 reports conversions at different $\mathrm{pH}$ and reaction times.
Overall these results lead to the following conclusions: i) in the $\mathrm{pH}$ range 5.2-6.0, the laccase activity is still sufficiently high to catalyse the regeneration of the oxoammonium mediator; ii) in the same $\mathrm{pH}$ range, the isomerization rate decreases drastically and it is much slower than the oxidative rearrangement, since no allylic alcohol 1c was anymore present in the reaction mixture; iii) $\mathrm{TEMPO}^{+} \mathrm{BF}_{4}^{-}$oxidizes the secondary allylic alcohol $1 \mathrm{c}$ very slowly; iv) the oxidative rearrangement of 1a needs an acid environment, since the conversion was less than $10 \%$ when using 0.2 molar equivalents of $\mathrm{TEMPO}^{+} \mathrm{BF}_{4}{ }^{-}$at neutral $\mathrm{pH}$.

Table 1. Optimization of $\mathrm{pH}$ and reaction time for the oxidative rearrangement of $\mathbf{1 a}$ using $\mathrm{TEMPO}^{+} \mathrm{BF}_{4}^{-}$. $^{[a]}$

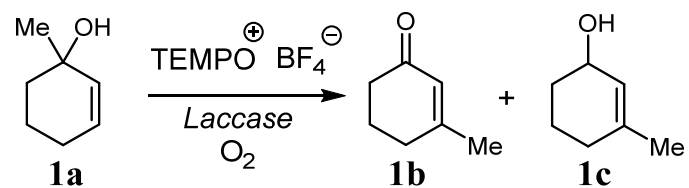

\begin{tabular}{ccccc}
\hline \multirow{2}{*}{$\begin{array}{c}\text { Time } \\
(\mathrm{h})\end{array}$} & $\mathbf{p H}$ & \multicolumn{3}{c}{ Reaction Mixture (\%) } \\
\cline { 3 - 5 } & & $\mathbf{1 a}$ & $\mathbf{1 b}$ & $\mathbf{1 c}$ \\
\hline \multirow{4}{*}{12} & 4.0 & 26 & 34 & 40 \\
& 5.2 & 11 & 89 & - \\
& 6.0 & 29 & 71 & - \\
& 7.0 & 94 & 2 & 4 \\
\hline \multirow{4}{*}{24} & 4.0 & 25 & 37 & 38 \\
& 5.2 & - & 100 & - \\
& 6.0 & - & 100 & - \\
\hline
\end{tabular}

[a] Screening conditions on $1 \mathrm{~mL}$ scale: [substrate] $=50 \mathrm{mM}$, T. versicolor laccase: $200 \mu \mathrm{g} / \mathrm{mL}$, TEMPO ${ }^{+} \mathrm{BF}_{4}{ }^{-} 20 \%$ in mol. eq., $1 \%$ DMSO co-solvent, under $\mathrm{O}_{2}$ atmosphere (balloon), buffers $(50 \mathrm{mM}): \mathrm{pH} 7.0$, phosphate; $\mathrm{pH} 6.0,5.2$, or 4.0, acetate; $30^{\circ} \mathrm{C}$; ${ }^{[b]}$ By GC-MS.

Due to the great success of TEMPO mediated oxidations, in the last decades we have assisted to the development of many similar reagents, which in several cases have proved to be more efficient than their progenitor. However, since their reactivity applied to the oxidative transposition of tertiary allylic alcohols is practically unknown, especially in water, we decided to test some of them, i.e. keto-ABNO, $\mathrm{ABNO}^{14}$ and its oxoammonium ${ }^{15}$ tetrafluoroborate salt together with the progenitor TEMPO (Figure 3, for the 
preparation of oxoammonium salts see SI); the results of this screening are shown in Table 2.
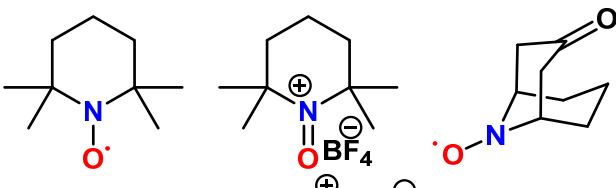

TEMPO

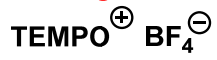

keto-ABNO
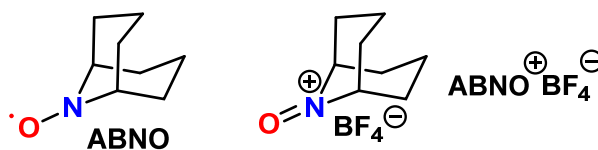

Figure 3. Mediators screened in the [1,3]-oxidative rearrangement of $\mathbf{1 a}$.

Noteworthy, at $\mathrm{pH} 5.2$, in the TEMPO series the oxoammonium salt was significantly more efficient than the nitroxyl radical ( $100 \%$ vs. $19 \%$, respectively). The trend was reversed for the ABNO based oxidants, the radical $A B N O$ being significantly more performing than its oxoammonium tetrafluoroborate salt $(60 \%$ vs. $4 \%$ conversion). For the keto-ABNO, it was not possible to prepare the tetrafluoroborate oxoammonium salt, however, both oxidative rearrangement and direct oxidation of the secondary allylic alcohol gave the enone in a very low yield.

Table 2. Mediator screening for the oxidative rearrangement of $1 \mathrm{a}$ at $\mathrm{pH}$ 5.2. ${ }^{[\mathrm{a}]}$

\begin{tabular}{cccc}
\multirow{2}{*}{ Mediator } & \multicolumn{3}{c}{ Reaction Mixture $(\%)^{[b]}$} \\
\cline { 2 - 4 } & $\mathbf{1 a}$ & $\mathbf{1 b}$ & $\mathbf{1 c}$ \\
\hline TEMPO & 33 & 19 & 48 \\
keto-ABNO & 40 & $<1$ & 60 \\
$\mathrm{ABNO}$ & 16 & 60 & 24 \\
$\mathrm{ABNO}^{+} \mathrm{BF}_{4}^{-}$ & 39 & 4 & 57
\end{tabular}

[a] Screening conditions on $1 \mathrm{~mL}$ scale: [substrate] $=50 \mathrm{mM}$, T. versicolor laccase: $200 \mu \mathrm{g} / \mathrm{mL}$, mediator $20 \%$ in mol. eq., $1 \%$ DMSO co-solvent, under $\mathrm{O}_{2}$ atmosphere (balloon), buffer: $50 \mathrm{mM}$ acetate, $\mathrm{pH}=5.2,30^{\circ} \mathrm{C}, 24 \mathrm{~h}$; ${ }^{[b]}$ By GC-MS.

In conclusion the optimal set-up for the oxidative rearrangement of $1 \mathrm{a}$ resulted to be: laccase (200 $\mu \mathrm{g} / \mathrm{mL})$, TEMPO ${ }^{+} \mathrm{BF}_{4}^{-}(20 \%$ in $\mathrm{mmol})$, at room temperature and $\mathrm{pH} 5.2$ under a static $\mathrm{O}_{2}$ atmosphere (Method A).

\section{Substrate Scope and Synthetic Application}

We focused our attention on three different sub-set of substrates: i) endocyclic allylic alcohols of medium/large rings; ii) endocyclic allylic alcohols bearing substituents with electron withdrawing groups (EWGs) and lastly iii) the more challenging exocyclic allylic alcohols. Most of tertiary allylic alcohols were prepared by addition of an organometallic reagent to a ketone (Grignard, organo- Lithium or Zinc reagents, see SI).

Initially, the substrates were oxidized on a preparative scale $(2.5 \mathrm{mmol})$ using the above established reaction conditions (Method A); the yields of the isolated products for starting materials of type i) and ii) are reported in Table 3.

The oxidation of cyclohexenol derivatives $\mathbf{2 a - 7 a}$ proceeded smoothly. Most of products were afforded in a nearly quantitative yield, especially the enones with an aliphatic or an aromatic substituent. The reaction condition set-up resulted successful also for substrates bearing a vinyl or an allyl substituent (6a7a). More remarkable, the isolation of the products was column chromatography-free.

In contrast, for substrates with a propargyl or an ethyl acetate side chain (8a-9a) no product was detected, even after prolonged reaction times (72 hours). However, in the seminal work of Iwabuchi, ${ }^{5}$ some tertiary alcohols were better oxidized in anhydrous acetonitrile, whereas for others the conversions were improved simply by adding a small amount of water to the reaction mixture. Apparently, depending upon to the type of mechanism, water can have a beneficial or detrimental effect on the reaction yield. Keeping this in mind, we took in account the possibility of using our catalytic system in organic solvents too. To this aim, the T. versicolor laccase was adsorbed on porous glass beads ${ }^{16}$ and tested in the oxidative transposition of model compound 1a in anhydrous $\mathrm{MeCN}$, keeping unchanged the other reaction conditions (Method B, Table 3). The conversion of $\mathbf{1 a}$ into $\mathbf{1 b}$ was slightly worse than that achieved in water, $(84 \%$ vs. $95 \%)$ and required a much longer reaction time (3 days vs. 24 h). However, by adopting method $\mathrm{B}$, it was possible to oxidize $9 \mathrm{a}$ into cyclohexenone $9 \mathrm{~b}$ in a satisfactory yield of $70 \%$. Instead, the oxidation of $\mathbf{8 a}$ gave an unforeseen result, i.e., the formation of cyclic enone $\mathbf{8 b}$, even if in a low yield. Surprisingly, in addition to the expected oxidative rearrangement an alkyne/allene isomerization occurred as well. ${ }^{17}$

Subsequently, we moved to the more appealing five-membered ring substrates (10a-18a, Table 3), since many fragrances are derivatives of cyclopentenone. Analogously to the cyclohexenol based substrates, the tertiary cyclopentenols were smoothly oxidized into the corresponding enones; even in this case the conversions were quantitative, and the product isolation was again very simple, with the only exception of $\mathbf{1 0 b}$, likely due to its high volatility.

Tetrasubstituted cyclopentenols 13a-16a underwent to oxidative rearrangement always in quantitative yields but in much shorter reaction times ( 3 hours instead of 1 day). This result is not surprising, being due to the higher strain of the tetrasubstituted cyclopentenols with respect to that of their trisubstituted homologues that facilitates the oxidative rearrangement.

Especially interesting was the oxidation of 17a, which gave information about the chemoselectivity of the laccase/TEMPO ${ }^{+} \mathrm{BF}_{4}^{-}$catalytic system. The oxidative rearrangement resulted prevailing over the 
Table 3. Substrate scope of laccase/TEMPO ${ }^{+} \mathrm{BF}_{4}^{-}$catalytic oxidative rearrangement. ${ }^{[\mathrm{a}]}$

\begin{tabular}{|c|c|c|c|c|}
\hline$\overline{\mathbf{R}}$ & Sub. & Prod. & Met. & $\begin{array}{l}\text { Yield } \\
(\%)^{[b]}\end{array}$ \\
\hline \multirow{2}{*}{$\mathrm{Et}$} & \multirow{2}{*}{$2 \mathbf{a}$} & \multirow{2}{*}{$2 \mathbf{b}$} & A & $>99^{[\mathrm{c}]}$ \\
\hline & & & $\mathrm{B}$ & 84 \\
\hline$n-\operatorname{Pr}$ & $\mathbf{3 a}$ & 3b & A & $97^{[\mathrm{c}]}$ \\
\hline$n-\mathrm{Bu}$ & $4 \mathbf{a}$ & $4 b$ & A & $98^{[\mathrm{c}]}$ \\
\hline $\mathrm{Ph}$ & $5 \mathbf{a}$ & $5 b$ & A & $>99^{[\mathrm{c}]}$ \\
\hline $\mathrm{CH}=\mathrm{CH}_{2}$ & $\mathbf{6 a}$ & $6 b$ & A & $>99^{[\mathrm{c}]}$ \\
\hline $\mathrm{CH}_{2} \mathrm{CH}=\mathrm{CH}_{2}$ & $7 \mathbf{a}$ & $7 b$ & A & $>99^{[\mathrm{c}]}$ \\
\hline $\mathrm{CH}_{2} \mathrm{C} \equiv \mathrm{CH}$ & $8 \mathbf{a}$ & & $\begin{array}{l}\text { A } \\
B\end{array}$ & - \\
\hline $\mathrm{CH}_{2} \mathrm{CO}_{2} \mathrm{Et}$ & $9 \mathbf{a}$ & $9 b$ & $\begin{array}{l}\text { A } \\
\text { B }\end{array}$ & $\begin{array}{c}- \\
70\end{array}$ \\
\hline
\end{tabular}

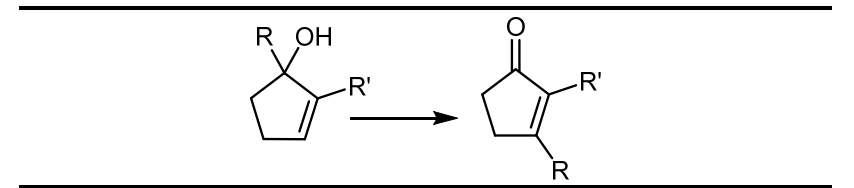

\begin{tabular}{|c|c|c|c|c|c|}
\hline $\mathbf{R}$ & $\mathbf{R}^{\prime}$ & Sub. & Prod. & Met. & $\begin{array}{l}\text { Yield } \\
(\%)^{[\mathrm{b}]}\end{array}$ \\
\hline$\overline{\mathrm{Me}}$ & $\mathrm{H}$ & $10 a$ & $10 \mathrm{~b}$ & $\mathrm{~A}$ & $70^{[\mathrm{c}]}$ \\
\hline$n-\mathrm{Bu}$ & $\mathrm{H}$ & $11 \mathrm{a}$ & 11b & A & $92^{[\mathrm{c}]}$ \\
\hline $\mathrm{Ph}$ & $\mathrm{H}$ & $12 a$ & $12 b$ & A & $>99^{[\mathrm{c}]}$ \\
\hline $\mathrm{Me}$ & $n$-Pent & $13 a$ & $13 b$ & A & $>99^{[\mathrm{c}, \mathrm{d}]}$ \\
\hline$n-\mathrm{Bu}$ & $\mathrm{Me}$ & $14 a$ & $14 \mathrm{~b}$ & A & $>99^{[\mathrm{c}, \mathrm{d}]}$ \\
\hline $\mathrm{Ph}$ & $\mathrm{Me}$ & $15 \mathbf{a}$ & $15 b$ & $\mathrm{~A}$ & $>99^{[\mathrm{c}, \mathrm{d}]}$ \\
\hline $\mathrm{CH}_{2} \mathrm{CH}=\mathrm{CH}$ & $n$-Pent & $16 a$ & $\begin{array}{l}16 b \\
17 b\end{array}$ & A & $>99^{[\mathrm{c}, \mathrm{d}]}$ \\
\hline $\mathrm{Me}$ & $\mathrm{CH}_{2} \mathrm{OH}$ & $17 \mathbf{a}$ & & A & $\begin{array}{c}>99 \\
(85: 15)^{[\mathrm{e}]}\end{array}$ \\
\hline $\mathrm{CH}_{2} \mathrm{CO}_{2} \mathrm{Et}$ & $n$-Pent & $18 a$ & $18 b$ & $\begin{array}{l}\mathrm{A} \\
\mathrm{B} \\
\end{array}$ & - \\
\hline
\end{tabular}

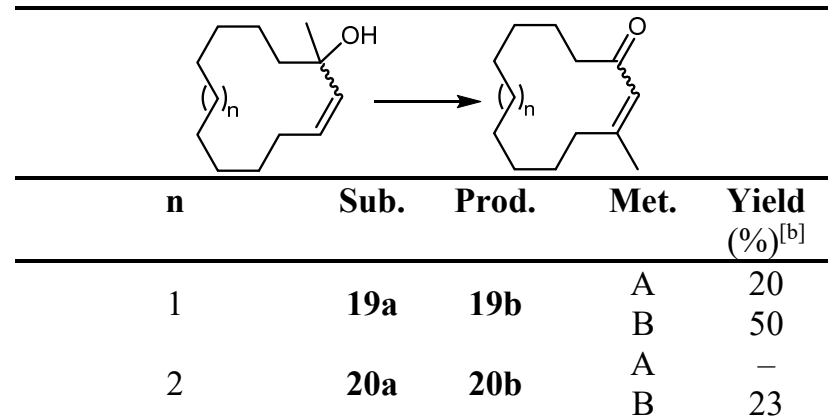

[a] Typical exp. cond. on $50 \mathrm{~mL}$ scale. Met. A in $\mathrm{H}_{2} \mathrm{O}$ : [Sub.] $=50 \mathrm{mM},\left[\mathrm{TEMPO}^{+} \mathrm{BF}_{4}^{-}\right]=10 \mathrm{mM}, T$. versicolor laccase: $200 \mu \mathrm{g} / \mathrm{mL}, 1 \%$ DMSO co-solvent, under $\mathrm{O}_{2}$ atmosphere (balloon), buffer $50 \mathrm{mM}$ : $\mathrm{pH}=5.2$ acetate, $30^{\circ} \mathrm{C}$, reaction time $24 \mathrm{~h}$; Met. B in MeCN: same cond. of A, except $2.5 \mathrm{gr}$ of immobilized laccase (glass beads/laccase 50:1 in weight), no buffer, reaction time 72 h, $300 \mathrm{mg}$ of MS $3 \AA$; ${ }^{[b]}$ After work-up; ${ }^{[c]}$ No column chromatography; ${ }^{[\mathrm{d}]}$ Reaction time 3 h; ${ }^{[e]}$ Ratio $\mathbf{1 7 b} / \mathbf{1 7 d}$. primary alcohol oxidation, since at the end of the reaction we recovered a mixture of enone $\mathbf{1 7 b}$ and aldehyde $17 \mathbf{d}$ in the ratio of $85: 15$, respectively (by ${ }^{1} \mathrm{H}$ NMR and GC-MS). The tertiary allylic alcohol 17d was not further oxidized to the corresponding enone, since substituents bearing EWGs such as the formyl group inhibit the oxidative transposition in water. In this regard the oxidation of $\mathbf{1 8 a}$ to give the fragrance ethyl dehydro-Jasmonate ${ }^{\circledR} \mathbf{1 8 b}$ was accomplished in an excellent yield of $90 \%$ but adopting the procedure in MeCN (method B). Finally, we tested our catalytic system with larger endocyclic tertiary allylic alcohols, i.e. 19a-20a, but, even if these substrates do not have electron withdrawing substituents, their oxidation with method A was not satisfactory, allowing only a $20 \%$ conversion in the case of 19a (Table 3). As macrocyclic alkenes are substantially less strained than cyclopentene and cyclohexene derivatives, these results suggest a possible crucial role of ring strain in the transposition mechanism in water. Instead, by adopting method $\mathrm{B}$ we afforded $\mathbf{1 9 b}$ and the fragrance dehydro-Muscone $\mathbf{2 0 b}$, but the yields, especially in the case of $\mathbf{2 0 b}$, were not totally satisfactory.

Our results confirm that the oxidative rearrangement of tertiary allylic alcohols is a synthetic strategy particularly suitable for the preparation of medium-sized cyclic enones, also because other synthetic strategies, such as Wittig olefination or aldol condensation, are not always applicable for these compounds. However, with the aim of broadening as much as possible the synthetic scope of our catalytic system, the transposition of exocylic allylic alcohols, i.e. 21a-26a (Table 4), was investigated, even if the corresponding $\alpha, \beta$-unsaturated products might be alternatively prepared with the above cited methodologies.

First, the oxidative rearrangement of allylic alcohols 21a-23a with method A failed, and we managed to obtain the fragrance isocitronellal $\mathbf{2 2 b}$ in a modest yield of $49 \%$, but with method B.

Much more interesting was the result obtained for the rearrangement of the diastereomeric mixture of alcohol 24a $\left(E / Z, \approx 1: 1\right.$, by $\left.{ }^{1} \mathrm{H}-\mathrm{NMR}\right)$, which gave mainly ketone $(E)-\mathbf{2 4 b}(d e>95 \%$, by GC-MS) in a yield of $77 \%$. By repeating the reaction at a lower $\mathrm{pH}$, the yield slightly improved, the same effect being observed also on the $p$-OMe derivative $\mathbf{2 5 a}$, which demonstrated to be a well-accepted substrate. Instead, when the hydrogen at para position of the phenyl ring was substituted with the electron withdrawing $-\mathrm{NO}_{2}$ group (26a, Table 4), or the $\mathrm{pH}$ was higher than 6.0 (data not shown), no enone formation was detected. The dynamic kinetic resolution of 24a-25a is likely due to three concomitant effects: i) the reaction goes first through the formation of the secondary allylic alcohol intermediate (for alcohols 24a-25a the acid catalysed isomerization is occurring even at $\mathrm{pH}$ 5.2), and the equilibrium between the two geometrical isomers is shifted toward the most stable $(E)$ diastereoisomer; ii) the $(E) /(Z)$ interconversion is much faster than the $\mathrm{TEMPO}^{+} \mathrm{BF}_{4}^{-}$catalysed oxidative process, and iii) the oxidation of the $(E)$ secondary 
alcohol is much faster than that of its $(Z)$ isomer (see SI for more details on the proposed mechanism).

Table 4. Oxidative rearrangement of exocyclic tertiary allylic alcohols. ${ }^{[a]}$

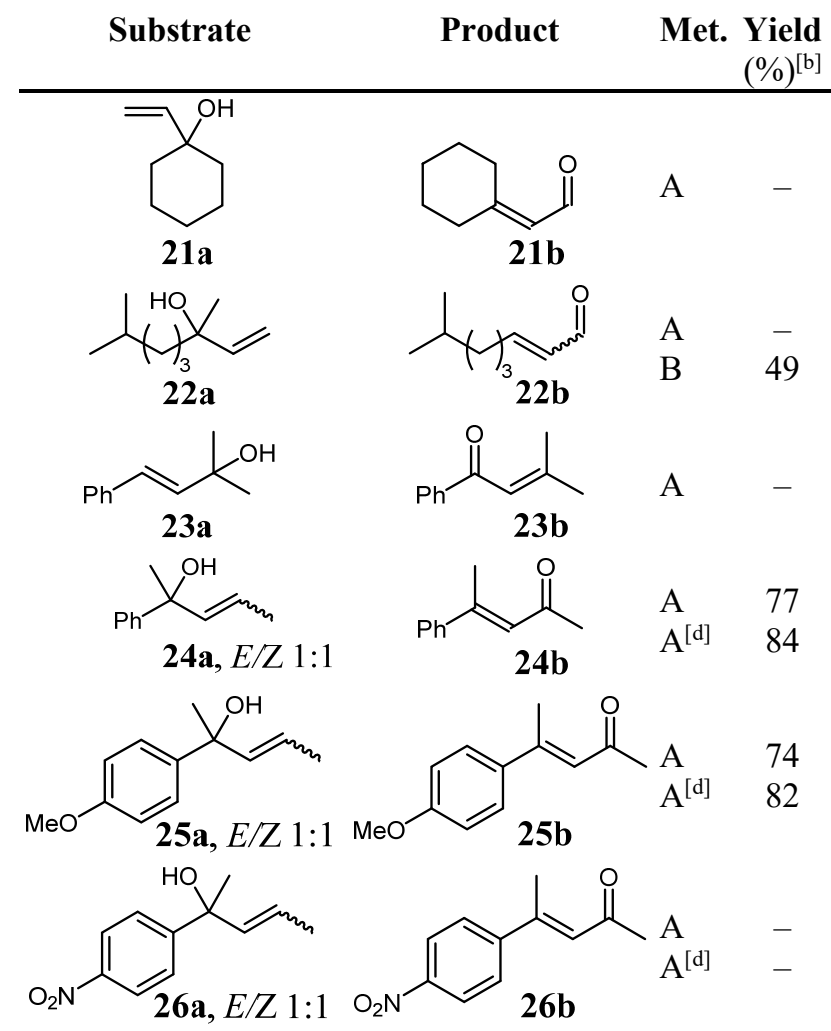

[a] Typical exp. cond. on $50 \mathrm{~mL}$ scale. See Table 3 for Met. A or B; ${ }^{[b]}$ After work-up; ${ }^{[\mathrm{d}]}$ At $\mathrm{pH}=4.0$, acetate buffer.

Finally, according to our ongoing research program on fragrances chemistry, we focused our attention on the development of synthetic routes for Magnolione ${ }^{\circledR}$ (28) and dehydro-Magnolione ${ }^{\circledR}(29)$ from the enone 16b obtained in the previously described work (Scheme 1).

Magnolione ${ }^{\circledR}$ is a fragrance structurally very similar to the well-known Jasmonate, but in comparison to the latter it displays a more intense floral jasminic note- odour and an increased chemical stability. It is commercialized as a mixture of its four stereoisomers, but, as often happen for chiral odorous molecules, its olfactory properties are strongly related to its (relative and/or absolute) stereochemistry. ${ }^{18}$ Indeed, the odour of both enantiomers of the trans diastereoisomer is weakly floral with a metallic bottom note, while the racemic mixture of the cis isomer exhibits a more pleasant and floral/fruity scent, ${ }^{19}$ even if for this diastereoisomer the $(2 S, 3 R)$-stereoisomer is much more intense than its enantiomer. Thus, in consideration of this odour profile, a diastereoselective synthesis might be sufficient to provide an added value to Magnolione $^{\circledR}$ fragrance. To this end, in the following we show how intermediate $\mathbf{1 6 b}$ is a suitable synthon for the diastereoselective synthesis of Magnolione $^{\circledR}$.

First of all, the endocyclic $\mathrm{C}=\mathrm{C}$ double bond of enone 16b was regioselectively reduced using classical Birch reaction conditions affording the transcyclopentanone 27 in $67 \%$ yield and with a de of $78 \%$ (by GC-MS and by ${ }^{1} \mathrm{H}-\mathrm{NMR}$ ). Then, to transform the terminal $\mathrm{C}=\mathrm{C}$ double bond into a methyl ketone, Wacker oxidation was exploited. We tested first the classical method ${ }^{20}$ (catalytic amount of $\mathrm{PdCl}_{2}$ with a stoichiometric amount of $\mathrm{CuCl}_{2}$ in $\mathrm{DMF} / \mathrm{H}_{2} \mathrm{O}$ under an $\mathrm{O}_{2}$ atmosphere at $60{ }^{\circ} \mathrm{C}$ ), but the yield was not sufficiently high due to the presence of several byproducts, principally chlorinated products. Hence, we decided to switch from $\mathrm{Cu}$ (II) to $\mathrm{Cu}$ (I) salt, since the latter minimizes the concentration of chlorine and consequently the side reactions. Indeed, by using the Tsuji-Wacker variant, we managed to isolate the transMagnolione $^{\circledR} 28$ in a good yield of $85 \%$, with an unaltered $d e .^{21}$

The attempt of transforming directly $\mathbf{1 6 b}$ into the dehydro-Magnolione ${ }^{\circledR} \mathbf{2 9}$ by Tsuji-Wacker oxidation failed, likely for the presence of the conjugated endocyclic $\mathrm{C}=\mathrm{C}$ double bond, which, in our case, seemed to inhibit the generation of the methyl ketone. Thus, a two steps synthetic pathway was explored: i) Markovnikov hydration of the terminal $\mathrm{C}=\mathrm{C}$ double bond of $16 \mathbf{b}$; ii) oxidation of the newly formed secondary alcohol (Scheme 1). (2S,3S)-3-allyl-2-pentylcyclopentan-1-one

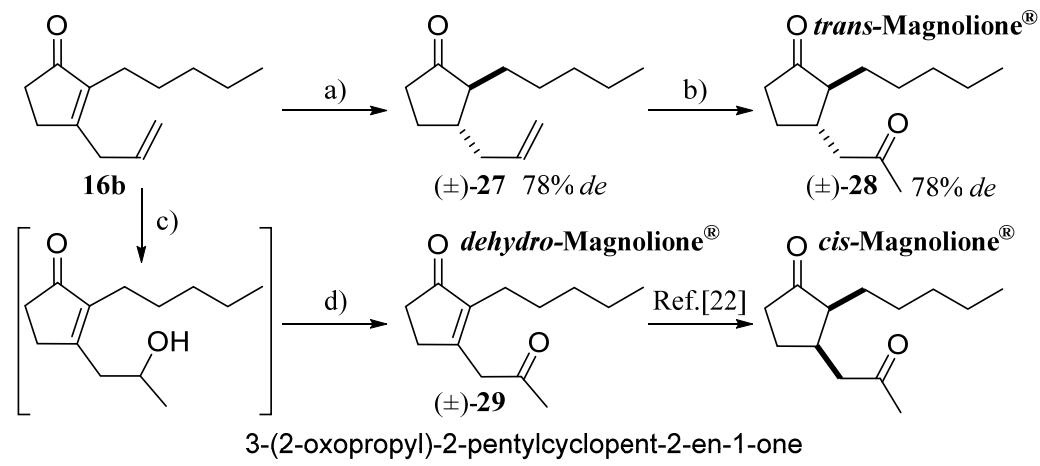

Scheme 1. a) Li, $t-\mathrm{BuOH}, \mathrm{NH}_{3(1)},-78^{\circ} \mathrm{C}, 67 \%$; b) $\mathrm{PdCl}_{2}, \mathrm{CuCl}, \mathrm{DMF} / \mathrm{H}_{2} \mathrm{O}(7: 1), \mathrm{O}_{2}$ bubbling, $85 \%$; c) $\mathrm{Hg}(\mathrm{OAc})_{2}, \mathrm{NaBH}_{4}$, $\mathrm{THF} / \mathrm{H}_{2} \mathrm{O}(1: 1)$; d) DMP, $\mathrm{CH}_{2} \mathrm{Cl}_{2}, 0{ }^{\circ} \mathrm{C}, 74 \%$ over two steps. 


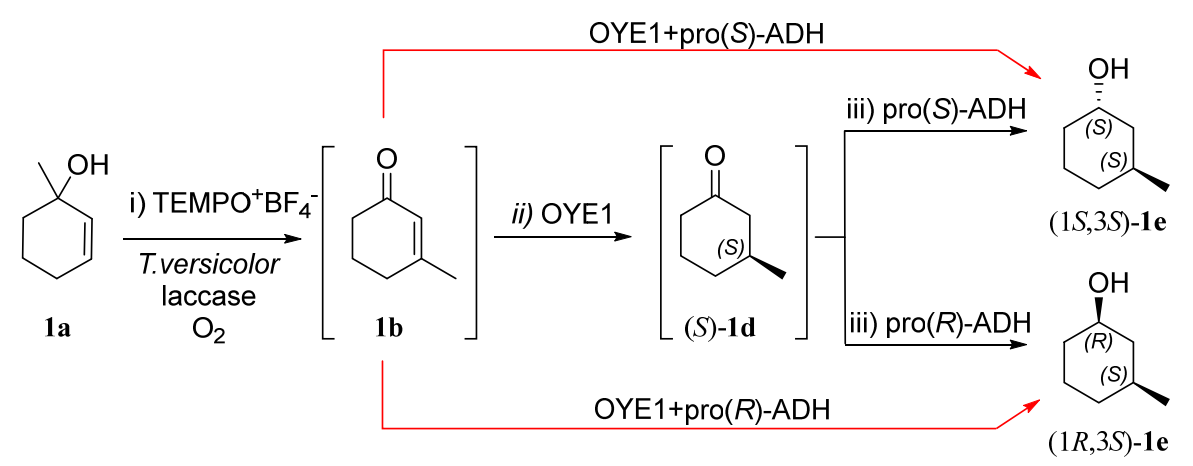

Scheme 2. Integrated chemo-multienzymatic process: i) [1,3]-oxidative transposition; ii) OYE1 catalyzed reduction of $\mathrm{C}=\mathrm{C}$ double bond; iii) ADH catalyzed carbonyl reduction.

Our strategy was successfully accomplished by oxymercuration of $\mathbf{1 6} \mathbf{b}$, followed by demercuration with $\mathrm{NaBH}_{4}$ affording the alcohol intermediate, which was oxidized to $\mathbf{2 9}$ with Dess-Martin periodinane (DMP) in an overall yield of $74 \%$, after column chromatography purification. We opted for a telescopic approach since the isolation of the alcohol intermediate resulted very difficult and low yielding.

Finally, the dehydro-Magnolione ${ }^{\circledR} 29$ might be transformed into the most pleasant stereoisomer of Magnolione $^{\circledR}$, i.e. the $(2 R, 3 S)-28$, by Ruthenium catalysed asymmetric hydrogenation of the conjugated $\mathrm{C}=\mathrm{C}$ double bond. ${ }^{22}$

\section{Integration of the Chemo-Enzymatic Oxidative Rearrangement in a Multienzymatic Cascade Process}

In the last years, several examples of how different enzymatic activities can be simply integrated either in sequential or cascade multi-step processes have been reported. ${ }^{23}$ Especially, we found very profitable the combination of ene-reductases (ERs, enzymes that catalyse the asymmetric reduction of electronically activated $\mathrm{C}=\mathrm{C}$ double bonds) with alcohol dehydrogenases (ADHs, enzymes capable of reducing/oxidising ketones/alcohols) in the stereoselective synthesis of flavours, ${ }^{24}$ fragrances, ${ }^{25}$ natural products ${ }^{26}$ or active pharmaceutical ingredients, ${ }^{27}$ starting from $\alpha, \beta$-unsaturated ketones. Therefore, in this regard, the TEMPO/laccasecatalysed rearrangement of a tertiary allylic alcohols could be an ideal partner of the ER-ADH catalytic system, allowing the set-up of a more complex and challenging multi-step process.

As proof of concept, the stereoselective transformation of $\mathbf{1 a}$ into the trans alcohol $(1 S, 3 S)-\mathbf{1 e}$ or cis alcohol $(1 R, 3 S)$-1e was herein investigated (Scheme 2).

Starting with, enone $\mathbf{1 b}$ is one of the benchmark substrates typically used in the screening of enereductases activity. So far, among all ERs tested, OYE1 and OYE2 (belonging to the Old Yellow Enzymes family) achieved the best conversion of $\mathbf{1 b}$ into the ketone $(S)-\mathbf{1 d}(74 \%$ and $60 \%$ for OYE1 and OYE2, respectively) with an excellent enantioselectivity (ee $>99 \%) .{ }^{28}$ To knowledge of the authors, for this substrate no ERs with $(R)$ selectivity have been so far reported.

Preparative scale reactions $(5 \mathrm{mM}, 50 \mathrm{mg}$ scale) afforded lower yields respect to those reported in literature, however we confirmed the $(S)$ absolute stereochemical configuration and the high optical purity of the product. After some optimization of the reaction conditions we managed to increase the conversion, by using OYE1 under an $\mathrm{N}_{2}$ atmosphere and a prolonged reaction time (for more details see SI). The NAD(P)H cofactor regeneration was carried out using a glucose dehydrogenase (GDH from Bacillus megaterium), with glucose as sacrificial co-substrate. ${ }^{29}$ To complete the cascade set-up, two crucial issues of the ADH catalysed step were left: i) the chemoselectivity and ii) the stereoselectivity. To this aim we tested a set of commercially available ADHs (recombinant and/or purified) from different sources (Table 5) on the reduction of a mixture of enone 1a and saturated ketone $(S)-\mathbf{1 b}(\approx 1: 1)$.

Remarkably, all the screened ADHs showed a complete chemoselectivity ${ }^{30}$ towards the reduction of ketone $(S)$-1d with the only exception of PLADH (ADH from Parvibaculum lavamentivorans), which was able to reduce also a small amount of enone $\mathbf{1 b}$ affording the side-product 1c.

Concerning the stereoselectivity, it turned out that READH (ADH from Rhodococcus erythropolis) and TBADH (ADH from Thermoanaerobium brockii) enzymes reduced the carbonyl group affording mainly the alcohol with $(S)$ configuration at the newly generated stereogenic centre, i.e. $(1 S, 3 S)-\mathbf{1 e}$, with an excellent de $>98 \%$; whereas PLADH and DRADH (ADH from Deinococcus radiodurans) showed an enantiocomplementary stereoselectivity affording mainly the cis diastereoisomer, $(1 R, 3 S)-\mathbf{1 e}(d e>90 \%)$. The other screened ADHs gave alcohol 1e, either cis or trans, in good yields but with modest des.

With the most performing ADHs and ER in our hands we tested the reductive cascade process (OYE1 + READH for the synthesis of trans-1e or OYE1 + PLADH for the synthesis of cis-1e) on a preparative scale. At the end, we managed to obtain discrete overall yields (around 80\% over two steps) only by 
lowering the substrate concentration from $5.0 \mathrm{mM}$ to $2.5 \mathrm{mM}$ (for more details see SI).

Table 5. Chemoselectivity and stereoselectivity of ADH mediated reductions. ${ }^{\text {[a] }}$

\begin{tabular}{|c|c|c|c|c|}
\hline \multirow[t]{2}{*}{ ADH } & \multicolumn{4}{|c|}{ Reaction Mixture $(\%)^{[\mathrm{b}]}$} \\
\hline & $1 \mathrm{~b}$ & 1d & $1 \mathrm{c}$ & $1 \mathrm{e}^{[\mathrm{c}, \mathrm{d}]}$ \\
\hline CPADH & 46.9 & 46.6 & $-[\mathrm{e}]$ & $6.5(69: 31)$ \\
\hline READH & 48.7 & 38.8 & $\_[\mathrm{e}]$ & $12.5(99: 1)$ \\
\hline BYADH & 43.6 & 56.4 & $-[\mathrm{e}]$ & - \\
\hline HLADH & 47.2 & 25.2 & $-[\mathrm{e}]$ & $27.6(83: 17)$ \\
\hline $\mathrm{PLADH}^{[\mathrm{f}]}$ & 38.7 & 0.6 & 5.3 & $55.4(5: 95)$ \\
\hline DRADH & 47.6 & - & $-[\mathrm{e}]$ & $52.4(1: 99)$ \\
\hline TBADH & 46.4 & 23.8 & $-[\mathrm{e}]$ & $29.8(99: 1)$ \\
\hline KRED & 46.8 & 0.2 & $-[\mathrm{e}]$ & $53.0(84: 16)$ \\
\hline
\end{tabular}

[a] Screening conditions on $1 \mathrm{~mL}$ scale: [substrate] $=5 \mathrm{mM}$, $\mathbf{1 b} / \mathbf{1 d} \approx 1: 1$ mixture, ADH $100 \mu \mathrm{g} \mathrm{mL}^{-1}$, GDH $4 \mathrm{U} \mathrm{mL}^{-1}, 4$ equiv. of glucose, $0.1 \mathrm{mM} \mathrm{NAD}(\mathrm{P})^{+}, 50 \mathrm{mM} \mathrm{KPi}$ buffer $\mathrm{pH}$ 7.0, $30{ }^{\circ} \mathrm{C}, 160 \mathrm{rpm}$, reaction time $12 \mathrm{~h}$; ${ }^{[b]}$ Conversion by GC-MS; [c] As a sum of cis + trans diastereoisomers; [d] Indicated in bracket the trans/cis ratio of the O-Silyl derivatives obtained by treatment with $\mathrm{TMSiCl}$ and $\mathrm{NEt}_{3}{ }^{[\mathrm{e}]}$ Not detected; ${ }^{[\mathrm{f}]}$ This ADH is likely contaminated with ER activity.

Lastly, we integrated the oxidative rearrangement with the reductive ER-ADH cascade process in a onepot three-step sequence. In the first step $1 \mathrm{a}(50 \mathrm{mM})$ was rearranged to $\mathbf{1 b}$ with the TEMPO $\mathrm{BF}_{4}^{-} /$laccase system at $\mathrm{pH} 5.2$ under an $\mathrm{O}_{2}$ atmosphere. After $24 \mathrm{~h}$, the reaction mixture was diluted to $2.5 \mathrm{mM}$, brought at neutral $\mathrm{pH}$ and, under a $\mathrm{N}_{2}$ atmosphere, OYE1 and the selected pro- $(S)$ or pro- $(R)$ ADH were added together with the cofactor regenerating system $\left(\mathrm{GDH}, \mathrm{NAD}(\mathrm{P})^{+}\right.$, glucose), affording the alcohol cis-1e or trans-1e in an overall yield of $85 \%$ and $82 \%$, respectively.

\section{Conclusion}

In summary, a "green" methodology for the $[1,3]$ oxidative transposition of tertiary allylic alcohols has been developed: we have exploited the tetrafluoroborate oxoammonium salt of TEMPO, an established non-heavy metal oxidant, in alternative to the very toxic oxochromium(VI)-based reagents. In the catalytic cycle, the Bobbitt's salt is efficiently regenerated by the laccase enzyme under aerobic conditions and at room temperature. The methodology is particularly suited for the preparation of cyclic enones of medium size (either five- or six-membered rings), since for this class of substrates the rearrangement's mechanism in water is favoured by the intrinsically higher ring-strain of these substrates. Instead, the rearrangement of endocyclic tertiary alcohols either bearing EWGs on the side chain or with rings of large size gave scarce results. For these kind of substrates, the oxidative rearrangement is usually more efficient in organic solvents. However, our catalytic system has proven to be very tolerant to both type of solvent. Indeed, by immobilizing laccase on porous glass beads we accomplished several oxidative rearrangements in $\mathrm{MeCN}$.

The practical usefulness of our methodology was demonstrated by the successful preparation of several fragrances, such as dehydro-Jasmonate, dehydroHedione $^{\circledR}$, dehydro-Muscone and iso-citronellal. In addition, we have shown that the cyclopentenone $\mathbf{1 6} \mathbf{b}$, bearing the allyl substituent, is a suitable intermediate for the diastereoselective synthesis of Magnolione ${ }^{\circledR}$ through the dehydro-Magnolione ${ }^{\circledR}$ intermediate.

Lastly, we have demonstrated that the oxoammonium/laccase mediated oxidative transpositions can be coupled in a sequential process with other two redox reactions: i) the OYE1 catalysed stereoselective reduction of the newly formed conjugated $\mathrm{C}=\mathrm{C}$ double bond followed by ii) the $\mathrm{ADH}$ catalysed asymmetric reduction of the prochiral ketone. This rather complex chemo-multienzymatic catalytic system has been tested on substrate 1a as a model; by judicious selection of a suited ADH was possible to obtain either the trans alcohol, i.e. $(1 S, 3 S)-1 \mathbf{e}$, or the cis alcohol, i.e. $(1 R, 3 S)-1 \mathrm{e}$, in a good overall yield and in both cases with an excellent diastereomeric excess.

\section{Experimental Section}

\section{General Information.}

Chemicals and solvents were purchased from suppliers and used without further purification, while, where required, the solvents were dried over molecular sieves $(4 \AA) .{ }^{1} \mathrm{H}$ and ${ }^{13} \mathrm{C}$ NMR spectra were recorded on a $400 \mathrm{MHz}$ spectrometer at room temperature, using TMS as an internal standard for ${ }^{1} \mathrm{H}$ and $\mathrm{CDCl}_{3}$ for ${ }^{13} \mathrm{C}$; chemical shifts $\delta$ are expressed in ppm relative to the reference. High-resolution MS spectra were recorded with a Q-TOF mass spectrometer, equipped with an ESI source. The GC-MS analyses of all compounds were performed on a column with a low polarity stationary phase $(30 \mathrm{~m} \times 0.25 \mathrm{~mm} \times 0.25 \mu \mathrm{m})$. Program temperature: $60{ }^{\circ} \mathrm{C}$

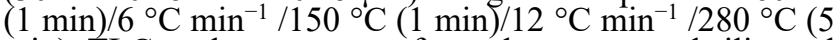
$\mathrm{min})$. TLC analyses were performed on precoated silica gel $60 \mathrm{~F}_{254}$ plates, and spots were visualized either by UV light $(254 \mathrm{~nm})$ or by spraying with phosphomolybdic acid reagent. All chromatographic separations were carried out on silica gel columns (230-400 mesh). Optical rotations were determined on a digital automatic polarimeter at $589 \mathrm{~nm}$ (sodium D line) and are given at $\mathrm{rt}$ in deg $\mathrm{cm}^{3} \mathrm{~g}^{-1} \mathrm{dm}^{-1}$.

\section{Enzymes and Strains.}

OYE1 from Saccharomyces pastorianus, OYE2 from Saccharomyces cerevisiae and GDH from Bacillus megaterium were overexpressed in E. coli BL21 (DE3) strains harbouring a specific plasmid, according to standard molecular biology techniques as described in ref. [29]. Protein concentrations were determined according to Bradford test, using bovine serum albumine (BSA) as a standard. CPADH from Candida parapsilosis and READH from Rhodoccocus erythropolis were purchased from Julich Chiral Solutions GmbH (now CODEXIS). PLADH from Parvibaculum lavamentivorans, DRADH from Deinococcus radiodurans, BYADH from Saccharomyces 
cerevisiae, HLADH from horse liver, TBADH from Thermoanaerobium brockii, KRED (ketoreductase) from an unspecified source and laccase from Trametes versicolor (activity $\geq 10 \mathrm{U} \mathrm{mg}^{-1}$ ) were purchased from Sigma-Aldrich.

\section{General Procedure for the Oxidative Rearrangement in Water (Method A)}

To a solution of a tertiary allylic alcohol $(1.0 \mathrm{mmol})$ in AcONa buffer (50 mM, pH 5.2, $20 \mathrm{~mL}, 200 \mu \mathrm{L}$ DMSO) were added $\mathrm{TEMPO}^{+} \mathrm{BF}_{4}^{-}(0.2 \mathrm{mmol}, 49 \mathrm{mg})$ and $T$. versicolor laccase $(4 \mathrm{mg})$ in a Schlenk tube. The reaction mixture was purged with pure $\mathrm{O}_{2}$ and then stirred at $30{ }^{\circ} \mathrm{C}$ for $24 \mathrm{~h}$ under an $\mathrm{O}_{2}$ atmosphere (balloon). Then, $\mathrm{HCl}(0.1$ $\mathrm{M})$ was added to the reaction mixture and the aqueous layer was washed with Pentane/Et ${ }_{2} \mathrm{O}(7: 3,10 \mathrm{~mL} \times 2)$. The combined organic layers was washed with brine (sat., $20 \mathrm{~mL}$ $x$ 1), dried over $\mathrm{Na}_{2} \mathrm{SO}_{4}$ and concentrated under vacuum. Where needed, the crude material was submitted to column chromatography purification.

\section{General Procedure for the Oxidative Rearrangement in MeCN (Method B)}

To a solution of a tertiary allylic alcohol $(1.0 \mathrm{mmol})$ in MeCN $(15 \mathrm{~mL})$ was added TEMPO ${ }^{+} \mathrm{BF}_{4}^{-}(0.15 \mathrm{mmol}, 49$ $\mathrm{mg})$ and laccase adsorbed on glass beads $(2.5 \mathrm{~g}$, beads/laccase $50: 1$ ) The solution was stirred at $30^{\circ} \mathrm{C}$ for 24 $\mathrm{h}$ under an $\mathrm{O}_{2}$ atmosphere (balloon). Then, the reaction mixture was filtered concentrated under reduced pressure and diluted with $\mathrm{Et}_{2} \mathrm{O}$. The organic layer was washed with brine (sat., $20 \mathrm{~mL}$ x 1), dried over $\mathrm{Na}_{2} \mathrm{SO}_{4}$ and concentrated under vacuum. The crude material was submitted to column chromatography purification.

\section{Synthesis of Magnolione ${ }^{\circledR}$ and dehydro-Magnolione ${ }^{\circledR}$}

3-Allyl-2-pentylcyclopent-2-enone (16b). Method A: $163.2 \mathrm{mg} ; 85 \%$ yield; $99 \%$ purity by $\mathrm{GC}\left(\mathrm{t}_{\mathrm{R}}=18.48 \mathrm{~min}\right)$ ${ }^{1} \mathrm{H} \mathrm{NMR}\left(400 \mathrm{MHz}, \mathrm{CDCl}_{3}\right): \delta 5.86-5.76(\mathrm{~m}, 1 \mathrm{H}), 5.16-5.12$ $(\mathrm{m}, 2 \mathrm{H}), 3.17(\mathrm{~d}, J=6.64,2 \mathrm{H}), 2.49(\mathrm{t}, J=3.92,2 \mathrm{H}), 2.36$ $(\mathrm{t}, J=4.72,2 \mathrm{H}), 2.18(\mathrm{t}, J=7.36,2 \mathrm{H}), 1.41-1.26(\mathrm{~m}, 6 \mathrm{H})$, $0.87(\mathrm{t}, J=6.56,3 \mathrm{H}) ;{ }^{13} \mathrm{C}$ NMR $\left(100 \mathrm{MHz}, \mathrm{CDCl}_{3}\right): \delta 209.7$, 170.4, 141.0, 133.2, 117.5, 35.7, 34.2, 31.8, 29.0, 28.2, 23.0, 22.4, 13.9; MS: m/z (\%) $192[\mathrm{M}]^{+}$(38), 177 (58), 163 (12), 151 (100), 135 (46); HRMS exact mass calculated for $[\mathrm{M}+\mathrm{H}]^{+}\left(\mathrm{C}_{13} \mathrm{H}_{21} \mathrm{O}\right)$ requires $\mathrm{m} / \mathrm{z} 193.1592$, found $\mathrm{m} / \mathrm{z}$ 193.1587.

(trans)-3-Allyl-2-pentylcyclopentanone (27). Lithium (140 mg, $20 \mathrm{mmol}$ ) was added to liquid ammonia $(60 \mathrm{~mL})$ at $-78^{\circ} \mathrm{C}$. After stirring for 15 minutes, a solution of $\mathbf{1 6 b}$ $(384 \mathrm{mg}, 2 \mathrm{mmol})$ and $t-\mathrm{BuOH}(0.92 \mu \mathrm{L}, 10 \mathrm{mmol})$ in THF $(4 \mathrm{~mL})$ were added at $-78^{\circ} \mathrm{C}$ and the reaction mixture was stirred for 45 minutes. Then, $\mathrm{H}_{2} \mathrm{O}(40 \mathrm{~mL})$ was carefully added at the same temperature and the reaction was warmed up to allow ammonia to evaporate. Hence, $\mathrm{Et}_{2} \mathrm{O}(2 \times 40 \mathrm{~mL})$ was added and the combined organic layer was washed with brine (sat., $50 \mathrm{~mL}$ ), dried over $\mathrm{Na}_{2} \mathrm{SO}_{4}$, filtered and concentrated under reduced pressure. ${ }^{31}$ The crude product was purified by column chromatography (gradient eluent: $n$ Hex/AcOEt, 95:5) to afford 27 as a colorless oil: $260 \mathrm{mg}$; $67 \%$ yield; $99 \%$ purity by $\mathrm{GC}\left(\mathrm{t}_{\mathrm{R}}(\right.$ trans $)=16.77 \mathrm{~min}, \mathrm{t}_{\mathrm{R}}($ cis $)$ $=17.40 \mathrm{~min}),{ }^{1} \mathrm{H}$ NMR $\left(400 \mathrm{MHz}, \mathrm{CDCl}_{3}\right): \delta 5.82(\mathrm{~m}, 1 \mathrm{H})$, 5.11-5.03 (m, 2H), 2.43-1.72 (m, 8H), $1.51(\mathrm{~m}, 4 \mathrm{H}), 1.27(\mathrm{~m}$, $4 \mathrm{H}), 0.88(\mathrm{t}, J=6.84,3 \mathrm{H}) ;{ }^{13} \mathrm{C} \mathrm{NMR}\left(100 \mathrm{MHz}, \mathrm{CDCl}_{3}\right): \delta$ $220.7,135.9$, 116.6, 54.2, 41.3, 38.7, 37.6, 32.1, 28.2, 26.6, 26.6, 22.4, 13.9; MS: m/z (\%) $194[\mathrm{M}]^{+}(1), 153$ (13), 124 (6), 109 (2), 97 (4), 83 (100).

3-(2-Oxopropyl)-2-pentylcyclopentanone (Magnolione ${ }^{\circledR}$, trans-28). To a stirred solution of $\mathrm{DMF} / \mathrm{H}_{2} \mathrm{O}(7: 1,5.6 \mathrm{~mL})$, $\mathrm{PdCl}_{2}(124 \mathrm{mg}, 0.7 \mathrm{mmol})$ and $\mathrm{CuCl}(693 \mathrm{mg}, 7 \mathrm{mmol}, 1$ eq.) were added under an $\mathrm{O}_{2}$ atmosphere. The reaction mixture was stirred for 1 hour to allow oxygen uptake. Then, 27 (1.36 g, $7 \mathrm{mmol}$ ) was added dropwise. The color of the solution turned from green to black within 10 minutes and returned gradually to green. ${ }^{32}$ After 6 hours, the reaction mixture was quenched with a solution of $\mathrm{HCl}(0.1 \mathrm{M}, 20 \mathrm{~mL})$, filtered on a pad of Celite and washed with $\mathrm{Et}_{2} \mathrm{O}(30 \mathrm{~mL})$. The organic layer was separated, washed with brine (sat., 20 $\mathrm{mL}$ ), dried over $\mathrm{Na}_{2} \mathrm{SO}_{4}$, filtered and concentrated under vacuum. The crude product was purified by column chromatography (gradient eluent: $n$-Hex/AcOEt from 90:10 up 80:20) to afford 29 as a colorless oil:1.25 g; $85 \%$ yield; $99 \%$ purity by $\mathrm{GC}\left(\mathrm{t}_{\mathrm{R}}=20.05 \mathrm{~min}\right),{ }^{1} \mathrm{H}$ NMR $(400 \mathrm{MHz}$, $\left.\mathrm{CDCl}_{3}\right): \delta 2.76-2.09(\mathrm{~m}, 8 \mathrm{H}), 1.73(\mathrm{~m}, 1 \mathrm{H}) ; 1.53(\mathrm{~m}, 2 \mathrm{H})$; $1.45-1.24(\mathrm{~m}, 7 \mathrm{H}) ; 0.88(\mathrm{t}, J=6.80,3 \mathrm{H}) ;{ }^{13} \mathrm{C}$ NMR $(100$ $\left.\mathrm{MHz}, \mathrm{CDCl}_{3}\right): \delta 219.5,207.1,54.2,48.4,37.6,37.1,32.0$, $30.4,28.0,27.3,26.4,22.4,13.9 ;^{33} \mathrm{MS}: \mathrm{m} / \mathrm{z}(\%) 210[\mathrm{M}]^{+}$ (7), 195 (1), 181 (1), 167 (1), 153 (100), 140 (37), 125 (23).

3-(2-Oxopropyl)-2-pentylcyclopent-2-enone (dehydroMagnolione ${ }^{\text {, }}$, 29). To a stirred, completely dissolved solution of $\mathrm{Hg}(\mathrm{OAc})_{2}(1.84 \mathrm{~g}, 5 \mathrm{mmol})$ in $\mathrm{H}_{2} \mathrm{O}(5 \mathrm{~mL}) \mathrm{THF}$ $(5 \mathrm{~mL})$ was added. The solution was bright yellow. Then, 29 $(960 \mathrm{mg}, 5 \mathrm{mmol}$ ) was added dropwise and the reaction mixture was stirred at room temperature till the solution faded. Thus, $\mathrm{NaOH}(6 \mathrm{M}, 3 \mathrm{~mL})$ and $\mathrm{NaBH}_{4}(0.5 \mathrm{M}, 5 \mathrm{~mL})$ in $3 \mathrm{M} \mathrm{NaOH}$ were carefully added, keeping the temperature below $25{ }^{\circ} \mathrm{C}$. The reaction was stirred for 2 hours till $\mathrm{Hg}$ precipitated as a shiny liquid. Hence, the reaction mixture was filtered on a Celite pad, washed with AcOEt $(20 \mathrm{~mL} x$ 2 ). The organic layer was extracted, washed with brine (sat., $20 \mathrm{~mL}$ ), dried over $\mathrm{Na}_{2} \mathrm{SO}_{4}$, filtered and the solvent was evaporated under reduced pressure. The crude, intermediate product was used in the next step without further purification. ${ }^{34}$ Then, the intermediate was dissolved in $\mathrm{CH}_{2} \mathrm{Cl}_{2}(50 \mathrm{~mL})$, trapped with a $\mathrm{CaCl}_{2}$ valve and the reaction mixture was cooled to $0^{\circ} \mathrm{C}$. Successively, DMP $(2.33 \mathrm{~g}, 5.5$ mmol) was slowly added and the mixture was stirred for 24 hours. Hence, the solution was extracted with $\mathrm{CH}_{2} \mathrm{Cl}_{2}(30$ $\mathrm{mL})$, washed with brine $(50 \mathrm{~mL})$, dried over $\mathrm{Na}_{2} \mathrm{SO}_{4}$, filtered and concentrated under vacuum. The titled product was purified by column chromatography (gradient eluent: $n$ Hex/AcOEt from 90:10 up 70:30) to afford 29 as a colorless oil: $770 \mathrm{mg} ; 74 \%$ yield; $99 \%$ purity by $\mathrm{GC}\left(\mathrm{t}_{\mathrm{R}}=20.89 \mathrm{~min}\right)$, ${ }^{1} \mathrm{H} \mathrm{NMR}\left(400 \mathrm{MHz}, \mathrm{CDCl}_{3}\right): \delta 3.56(\mathrm{~s}, 2 \mathrm{H}), 2.54(\mathrm{t}, J=4.76$, $2 \mathrm{H}), 2.39$ (qt, $J=2.72,2 \mathrm{H}), 2.24(\mathrm{~s}, 3 \mathrm{H}), 2.16(\mathrm{t}, J=7.52$, $2 \mathrm{H}), 1.39-1.24(\mathrm{~m}, 6 \mathrm{H}), 0.87(\mathrm{t}, J=6.84,3 \mathrm{H}) ;{ }^{13} \mathrm{C} \mathrm{NMR}(100$ $\left.\mathrm{MHz} \mathrm{CDCl}_{3}\right): \delta 208.9,203.0,164.0,143.1,45.8,34.3,31.7$, $30.2,29.9,27.9,23.3,22.3,13.8 ; \mathrm{MS}: \mathrm{m} / \mathrm{z}(\%) 208[\mathrm{M}]^{+}(5)$ $193(16), 179(2), 165(9), 151$ (100), 137 (15); HRMS exact mass calculated for $[\mathrm{M}+\mathrm{H}]^{+}\left(\mathrm{C}_{13} \mathrm{H}_{21} \mathrm{O}_{2}\right)$ requires $\mathrm{m} / \mathrm{z}$ 209.1542 , found $\mathrm{m} / \mathrm{z} 209.1548$.

To a solution of $1 \mathrm{a}(1.0 \mathrm{mmol})$ in AcONa buffer $(50 \mathrm{mM}$, $\mathrm{pH} 5.2,10 \mathrm{~mL}, 800 \mu \mathrm{L}$ DMSO) were added TEMPO ${ }^{+} \mathrm{BF}_{4}^{-}$ $(0.15 \mathrm{mmol}, 37 \mathrm{mg})$ and $T$. versicolor laccase $(4 \mathrm{mg})$ in a Schlenk tube. The reaction mixture was purged with pure $\mathrm{O}_{2}$ and then stirred at $30{ }^{\circ} \mathrm{C}$ under $\mathrm{O}_{2}$ atmosphere (balloon). After $24 \mathrm{~h}$ the reaction mixture was purged with $\mathrm{N}_{2}$, diluted with a phosphate buffer solution $(50 \mathrm{mM}, \mathrm{pH} 7,190 \mathrm{~mL})$, and then glucose $(720 \mathrm{mg}, 4 \mathrm{mmol}), \mathrm{NAD}(\mathrm{P})^{+}(14 \mathrm{mg}+14$ $\mathrm{mg})$, GDH (4 U/mL), OYE1 $(80 \mu \mathrm{g} / \mathrm{mL})$, and PLADH (250 $\mu \mathrm{g} / \mathrm{mL})$ or and READH $(250 \mu \mathrm{g} / \mathrm{mL})$, were added. After 48 $\mathrm{h}$, the reaction mixture was extracted with a pentane/ $/ \mathrm{Et}_{2} \mathrm{O}$ solvent mixture $(7: 3,40 \mathrm{~mL} \times 3)$. The combined organic layers was dried over $\mathrm{Na}_{2} \mathrm{SO}_{4}$ and the solvent was removed under reduced pressure. The crude material was submitted to column chromatography purification (Pentane/Et ${ }_{2} \mathrm{O}, 9: 1$, $\mathrm{SiO}_{2}$ ) affording alcohol $\mathbf{1 e}$.

(1S,3S)-3-Methylcyclohexanol ((1S,3S)-1e. Bioreduction with OYE1 and READH: $97 \mathrm{mg}, 85 \%$ isolated yield, $[\alpha]_{\mathrm{D}}=$ $+6.7\left(\right.$ c $\left.1.0, \mathrm{CH}_{2} \mathrm{Cl}_{2}\right)$, vs. Lit. $[\alpha]_{\mathrm{D}}=6.7$ (neat). ${ }^{35}{ }^{1} \mathrm{H} \mathrm{NMR}$ (400 MHz, CDCl $\left.\mathrm{CD}_{3}\right) \delta 4.06-4.01(\mathrm{~m}, 1 \mathrm{H}), 1.72-1.57(\mathrm{~m}, 4 \mathrm{H})$, $1.53-1.46(\mathrm{~m}, 2 \mathrm{H}), 1.32-1.17(\mathrm{~m}, 2 \mathrm{H}), 1.01-0.91(\mathrm{~m}, 1 \mathrm{H})$, $0.88(\mathrm{~d}, J=6.7,3 \mathrm{H}) ;{ }^{13} \mathrm{C} \mathrm{NMR}(100 \mathrm{MHz}, \mathrm{CDCl} 3): \delta 66.9$, 41.6, 34.2, 33.1, 26.5, 21.9, 20.0; MS: m/z (\%) $96[\mathrm{M}-18]^{+}$ $94(51), 81(77), 71(100), 57$ (49).

(1R,3S)-3-methylcyclohexanol $((1 R, 3 S)-1$ e. Bioreduction with OYE1 and PLADH: $93 \mathrm{mg}, 82 \%$ isolated yield, $[\alpha]_{\mathrm{D}}=$ $<3.0\left(\left(c 1.0, \mathrm{CH}_{2} \mathrm{Cl}_{2}\right)\right.$, lit. $[\alpha]_{\mathrm{D}}=+1.8$ (neat). ${ }^{36}{ }^{1} \mathrm{H} \mathrm{NMR}(400$ 
$\left.\mathrm{MHz}, \mathrm{CDCl}_{3}\right): \delta 3.56(\mathrm{tt}, J=10.9,4.3,1 \mathrm{H}), 1.99-1.88(\mathrm{~m}, 2 \mathrm{H})$ $1.79-1.70(\mathrm{~m}, 1 \mathrm{H}), 1.63-1.56(\mathrm{~m}, 1 \mathrm{H}), 1.51-1.34(\mathrm{~m}, 2 \mathrm{H})$, $1.30-1.19(\mathrm{~m}, 2 \mathrm{H}), 1.17-1.03(\mathrm{~m}, 2 \mathrm{H}), 0.92(\mathrm{~d}, J=6.6,3 \mathrm{H})$, 0.91-0.85 (m, 1H); ${ }^{13} \mathrm{C}$ NMR $\left(100 \mathrm{MHz}, \mathrm{CDCl}_{3}\right): \delta 70.4$, 44.4, 35.2, 34.0, 31.3, 24.1, 22.2; MS: m/z (\%) $96[\mathrm{M}-18]^{+}$ 94 (51), 81 (65), 71 (100), 57 (32).

\section{Acknowledgements}

This work was supported by Fondazione Cariplo (grant no. 20140568). We thank POR-Lombardia, VIPCAT project for the financial support as well. We thank Mr. Natale Lucente for the preliminary work on the rearrangement of exocyclic tertiary alcohols.

\section{References}

[1] F. A., Luzzio, Tetrahedron 2012, 68, 5323-5339.

[2] D. Pybus and C. S. Sell in Chemistry of Fragrances: From Perfumer to Consumer, II ed., RSC, 2006.

[3] M., Shibuya; S., Ito; M., Takahasci; Y., Iwabuchi Org. Lett. 2004, 6, 4303-4306.

[4] J.-M., Vatéle Tetrahedron 2010, 66, 904-912.

[5] M., Shibuya; M., Tomizawa; Y., Iwabuchi J. Org. Chem. 2008, 73, 4750-4752.

[6] M., Shibuya; M., Tomizawa; Y., Iwabuchi Org. Lett. 2008, 10, 4715-4718.

[7] a) R. A., Sheldon; I. W. C. E., Arends Adv. Synth. Catal. 2004, 346, 1051-1071. b) S., Riva Trend Biotechnol. 2006, 24, 219-226.

[8] M., Fabbrini; C., Galli; D., Macchitella Tetrahedron Lett. 2001, 42, 7551-7553.

[9] A., Diaz-Rodriguez; I., Lavandera; S., Kanbak-Aksu; R. A., Sheldon; V., Gotor; V., Gotor-Fernandez Adv. Synth. Catal. 2012, 354, 3405-3408.

[10] a) L., Montero-Martinez; V., Gotor; V., GotorFernandez; I., Lavandera Green Chem. 2017, 19, 474480; b) E., Brenna; M., Crotti; F. G., Gatti; D., Monti; F., Parmeggiani; A., Pugliase; F., Tentori Green Chem. 2017, 19, 5122-5130.

[11]D., Paprocki; D., Koszelewski; A., Żądło; P. Walde; R., Ostaszewski RSC Adv. 2016, 6, 68231-68237.

[12] a) E. I., Solomon; U. M., Sundaram; T. E., Machonkin Chem. Rev. 1996, 96, 2563-2605; b) H., Claus Arch. Microbiol. 2003, 179, 145-150; c) S. G., Burton Curr. Org. Chem. 2003, 7, 1317-1331.

[13]R. R., Leleti; H., Bin; M., Prashad; J., Repic Tetrahedron Lett. 208, 48, 8505-8507.

[14] M., Shibuya; M., Tomizawa; Y., Sasano; Y., Iwabuchi J. Org. Chem. 2009, 74, 4619-4622.

[15]N., Merbouh; J. M., Bobbitt; C., Bruckner Org. Prep. Proced. Int. 2004, 36, 1-31.

[16] S., Riva; A., Intra; S., Nicotra; B., Danieli Adv. Synth. Catal. 2005, 347, 973-977.
[17] R., Shen; J., Yang; B., Luo; L., Zhang; L.-B., Han Adv. Synth. Catal. 2016, 358, 3897-3906.

[18] Q., Stang; G., Helmchen; Helv. Chim. Acta 2005, 88, 2738-2746.

[19]E., Brenna; C., Fuganti; F. G., Gatti; S., Serra Chem. Rev. 2011, 111, 4036-4072.

[20] J., Smidt; W., Hafner; R., Jira; J., Sedlmeier; Sieber, R.; R., Ruttinger; H., Kojer Angew. Chem. 1959, 71, 176.

[21] J., Tsuji Synthesis 1984, 369.

[22] Patent: Firmenich, US572886.

[23] J. H., Schrittwieser; S., Velikogne; M., Hall; W. Kroutil Chem. Rev. 2018, 118, 270-348.

[24]E., Brenna; M., Crotti; F. G., Gatti; L., Marinoni; D., Monti; S., Quaiato J. Org. Chem. 2017, 82, 2114-2122.

[25]E. Brenna; M. Crotti; F. G., Gatti; D. Monti; F. Parmeggiani; A., Pugliese J. Mol. Catal. B: Enzym. 2015, 114, 37-41.

[26] a) E. Brenna; M. Crotti; F. G., Gatti; D. Monti; F. Parmeggiani; A., Pugliese Molecules 2017, 22, 15911600; b) E., Brenna; F. G., Gatti; D. Monti; F., Parmeggiani; A., Sacchetti; J., Valoti J. Mol. Catal. B: Enzym. 2015, 114, 77-85.

[27] a) E., Brenna; F. G., Gatti; D. Monti; F, Parmeggiani; A. Sacchetti E. Chem. Commun. 2012, 48, 79-81; b) E., Brenna; M., Crotti; F. G., Gatti; L., Malpezzi; D., Monti; A., Sacchetti J. Org. Chem. 2013, 78, 4811-4822.

[28] M., Hall; C., Stueckler; B., Hauer; R., Stuermer; T., Friedrich; M., Breuer; W., Kroutil; K., Faber Eur. J. Org. Chem. 2008, 1511-1516.

[29] M., Bechtold; E., Brenna; F. C., Femmer; F. G., Gatti; S. Panke; F., Parmeggiani; A., Sacchetti Org. Process Res. Dev. 2012, 16, 269-276.

[30]E., Brenna; F. G., Gatti; D., Monti; F, Parmeggiani; A., Sacchetti ChemCatChem 2012, 4, 653-659.

[31] M. F., Schneider; H., Junga; S., Blechert Tetrahedron 1995, 51, 13003-13014.

[32] J., Tsuji; H., Nagashima; H., Nemoto Org. Synth. 1984, $62,9$.

[33], M.I., Donnoli; P., Scafato; M., Nardiello; D., Casarini; E., Giorgio, C., Rosini. Tetrahedron 2004, 60, 49754981.

[34] J. M., Jerkunica; T. G.; Traylor Org. Synth. 1988, 6, 766.

[35] A. K.; Macbeth; J. A., Mills J. Chem. Soc. 1947, 205208.

[36]D. S., Noyce; D. B., Denney J. Am. Chem. Soc. 1952, $74,5912-5915$ 


\section{FULL PAPER}

Enzymatic-Organo-Catalyzed Rearrangement of Tertiary Allylic Alcohols: Synthetic Applications and Integration into a Cascade Process

Adv. Synth. Catal. Year, Volume, Page - Page

Author(s), Francesco G. Gatti* et al.
TOC Graphic

Metal-free OxidativeTransposition _. 23 examples, high yields, Fragrance Chemistry synthones

$\mathrm{TEMPO}^{+} \mathrm{BF}_{4}{ }_{4}^{-}$llaccase Alcohol Dehydrogenase

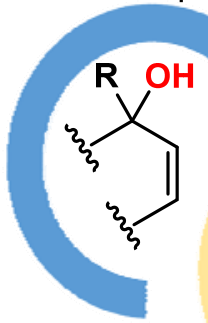

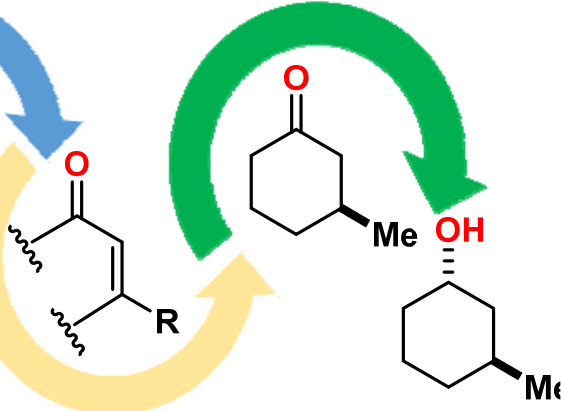

Ene-Reductase 